\title{
Estimating locus heterogeneity in autosomal dominant polycystic kidney disease (ADPKD) in the Spanish population
}

Unidad de Genética Molecular, Hospital Ramón y Cajal, Crtra Colmenar km 9.1, 28034-Madrid, Spain. B Peral

J L San Millán

C Hernández

A Valero

F Moreno

Centre d'Etude du Polymorphisme Humain, 27 rue Juliette Dodu, 75010

Paris, France.

G M Lathrop

J S Beckmann

Correspondence to Dr San Millán.

Received 5 March 1993. Revised version accepted Revised version

Belén Peral, José L San Millán, Concha Hernández, Ana Valero, G Mark Lathrop, Jacques S Beckmann, Felipe Moreno

\begin{abstract}
Although most mutations causing ADPKD in European populations have been mapped to the PKD1 locus on chromosome 16, some of them appear to be unlinked to this locus. To evaluate the incidence of unlinked mutations in Spain we have typed 31 Spanish families from different geographical sites for six closely linked DNA polymorphic marker loci flanking PKD1 detected by probes D16S85, D16S21， D16S259, D16S125, D16S246, and D16S80. Multilocus linkage analysis indicated that in $\mathbf{2 6}$ families the disease resulted from PKD1 mutations, whereas in three families it resulted from mutations in a locus other than PKD1. The two other families were not informative. Using the HOMOG test, the incidence of the PKD1 linked mutations in Spain is $85 \%$. Multipoint linkage analysis in the 26 PKD1 families showed that the disease locus lies in the interval between D16S259(pGGG1) and D16S125(26.6).

(f Med Genet 1993;30:910-13)
\end{abstract}

Autosomal dominant polycystic kidney disease (ADPKD1) is one of the most frequent inherited monogenic disorders, affecting 1 per 1000 of the European population. It is characterised by the formation and progressive enlargement of cysts in both kidneys that often lead to end stage renal failure. Other manifestations of the disease are hepatic cysts, cardiac valvular abnormalities, intracranial aneurysms, and hypertension. The penetrance of the disease depends on age and its expressivity is variable. Some patients have clinical symptoms in early childhood whereas others remain asymptomatic for many years. ${ }^{1}$ ADPKD accounts for $9 \%$ of patients requiring haemodialysis or renal transplantation in Spain. ${ }^{2}$

Most of the ADPKD mutations have been mapped to the short arm of chromosome 16 in the region $16 \mathrm{p} 13.3$, within a locus designated PKD $1{ }^{34}$ PKD1 is linked to the $\alpha$ globin gene cluster and is located on its proximal side. A dozen anonymous RFLP DNA markers have been developed and used to construct detailed genetic and physical maps of the region as well as to study ADPKD families. ${ }^{4-6}$ The analysis of recombinational events in the region have shown that PKD1 is located within a region shorter than $750 \mathrm{~kb}$ between the loci D16S125 proximally and D16S259 distally. ${ }^{78}$

In a small number of families the mutations causing the disease have been shown to segre- gate independently of PKD1 linked markers, indicating that, when altered, a gene(s) other than PKD1 may produce ADPKD..$^{9-11}$ To evaluate the relative incidence of the alternative form of the disease in the Spanish population we have studied 31 unrelated ADPKD families with six polymorphic DNA markers flanking PKD1. This study also provided the opportunity to confirm the location of PKD1 with respect to those marker loci by linkage analysis.

\section{Materials and methods}

FAMILIES AND CLINICAL DETAILS

The families were diagnosed clinically in different hospitals in Spain. Every asymptomatic member of a family at risk was examined by ultrasonographic scanning. Subjects showing at least one cyst in one kidney and more than one in the other were considered to be affected. ${ }^{1}$ Each family included at least three affected persons or two affected and two unaffected members. A total of 31 ADPKD families was included in this study. The first ascertained member of each family was designated the index case. Of the 31 ADPKD probands, 22 were identified at renal clinics and they had severe renal impairment and were on dialysis or had renal transplants. The other nine index cases were identified through adult nephrologists (8) and genetics clinics (1) and were being treated for complications of ADPKD other than severe renal impairment, including a patient with intracranial aneurysm and five patients with a family history of ADPKD (necropsy report of the disease or death with a clinical diagnosis of ADPKD). This study was approved by the ethics and clinical trials committee of the Ramón y Cajal Hospital.

\section{DNA ANALYSIS}

Standard procedures for DNA extraction from white blood cells, digestion with restriction enzymes, electrophoresis, Southern blotting, and hybridisation were used. Six polymorphic markers around the PKD1 locus were used (table 1). The DNA probes were excised from plasmid vectors before being labelled by the oligolabelling method. ${ }^{12}$ Families in which linkage between ADPKD and chromosome $16 \mathrm{p}$ markers could not be shown were typed with probe YNH24 (locus D2S44), which detects a VNTR polymorphism. ${ }^{13}$ 
Table 1 Chromosome 16 marker loci flanking PKD1.

\begin{tabular}{|c|c|c|c|c|}
\hline \multirow[b]{2}{*}{ Locus/probe } & \multirow[b]{2}{*}{$\begin{array}{l}\text { RFLP } \\
\text { enzyme }\end{array}$} & \multirow[b]{2}{*}{$\begin{array}{l}\text { Allele } \\
\text { size (kb) }\end{array}$} & \multicolumn{2}{|c|}{ Allele frequencies } \\
\hline & & & $\begin{array}{l}\text { Previous } \\
\text { reports }\end{array}$ & $\begin{array}{l}\text { This } \\
\text { study }\end{array}$ \\
\hline $\begin{array}{l}\text { D16S85/3'HVR } \\
\text { D16S21/2BP5 }\end{array}$ & $\begin{array}{l}\text { PvuII } \\
\text { Pst I }\end{array}$ & $\begin{array}{l}\text { A-X } \\
\text { S6 (1.3) } \\
\text { S7 (1.0) }\end{array}$ & $\begin{array}{l}0.37 \\
0.63\end{array}$ & $\begin{array}{l}0.48 \\
0.52\end{array}$ \\
\hline D16S259/pGGG1 & Pst $\mathbf{I}$ & $\begin{array}{l}\text { U3 }(1.9) \\
\text { U4 }(1.5) \\
\text { U5 }(1 \cdot 2)\end{array}$ & $\begin{array}{l}0 \cdot 15 \\
0 \cdot 61 \\
0 \cdot 24\end{array}$ & $\begin{array}{l}0 \cdot 12 \\
0.69 \\
0 \cdot 19\end{array}$ \\
\hline D16S125/26.6PROX & TaqI & $\begin{array}{l}\text { E1 }(5.8) \\
\text { E2 }(0.85)\end{array}$ & $\begin{array}{l}0.27 \\
0.73\end{array}$ & $\begin{array}{l}0.45 \\
0.55\end{array}$ \\
\hline D16S246/218EP6 & Pst I & $\begin{array}{l}\mathrm{Ha}(1.5) \\
\mathrm{Hb}(1.2) \\
\mathrm{Hc}(1 \cdot 1)\end{array}$ & $\begin{array}{c}0.36 \\
0.64 \\
?\end{array}$ & $\begin{array}{l}0.42 \\
0.55 \\
0.03\end{array}$ \\
\hline D16S80/24.1 & TaqI & $\begin{array}{l}\text { B1 }(3.8) \\
\text { B2 }(1.5 / 1 \cdot 3) \\
\text { B3 }(1.5)\end{array}$ & $\begin{array}{l}0.80 \\
0.13 \\
0.07\end{array}$ & $\begin{array}{l}0 \cdot 77 \\
0 \cdot 13 \\
0 \cdot 10\end{array}$ \\
\hline
\end{tabular}

The PvuII alleles at D16S85 are of many different sizes. Data from chromosome 16 markers and allele frequencies are from ref 4

\section{LINKAGE ANALYSIS}

Linkage analysis was carried out using version 5.1 of the LINKAGE program package. ${ }^{14}$ Taking into account that the penetrance of the disease is age dependent, the unaffected children of an affected parent were distributed in three liability classes with penetrances of 0.5 , 0.85 , and 0.95 for subjects below 20 years, 21 to 30 years, and older than 20 years of age, respectively..$^{15}$ No differences in recombination rates between sexes and absence of genetic interference and spontaneous mutations were assumed in the calculations. Multipoint analyses were run using LINKMAP with a fixed order of marker loci as follows: D16S85-0.02D16S21-0.01-D16S259-0.03-D16S125-0.02D16S246-0.02-D16S80. ${ }^{5716}$ Locus heterogeneity for ADPKD families was evaluated using the HOMOG program (version 3.1). ${ }^{17}$ HOMOG carries out a homogeneity test under the following alternative hypotheses: absence of linkage (H0), one group of families, with the disease locus linked to marker loci $(\mathrm{H} 1)$, and two family groups, one linked and one unlinked (H2). HOMOG tests one hypothesis against another. This is carried out as likelihood ratio tests with $\mathrm{p}$ values calculated where appropriate from the asymptotic $\chi^{2}$ distribution of the likelihood ratio statistics. ${ }^{17}$

\section{Results}

A total of 126 affected and 195 unaffected subjects, 132 of whom were at risk, was characterised for the six DNA polymorphisms described in table 1 . The allele frequencies in the Spanish population were similar to those found in other European populations except for the RFLP TaqI alleles detected by probe 26.6PROX at locus D16S125. In addition, the probe 218EP6 showed a previously undescribed Pst I allele of $1.1 \mathrm{~kb}$ at locus D16S246, whose frequency was $3 \%$. As expected, lod score analyses showed significant evidence of linkage between the marker loci (data not shown).

The results of pairwise linkage analyses between ADPKD and each marker loci gave strong evidence in favour of linkage in every case. As shown in table $2 \mathrm{~A}$, the highest maximum lod score was found for linkage of the disease and D16S85 (12.45 at a recombination fraction of 0.091), not a surprising result given the high informativity of the marker $3^{\prime}$ HVR (D16S85). ${ }^{18}$ However, when the $\mathrm{Z}$ values obtained from single families were considered, we found that linkage of the disease to PKD1 linked markers was not supported in some of the pedigrees.

To evaluate linkage better in our sample of families we performed multipoint analysis within chromosome 16 intervals using the order and the estimates of recombination fractions between loci drawn from published reports (see Methods). The resulting multipoint lod scores were used for testing locus heterogeneity using version 3.1 of the HOMOG program. ${ }^{17}$ This test estimates the relative odds in favour of heterogeneity $(\mathrm{H} 2 / \mathrm{H} 1)$, the proportion of families showing linkage to the markers $(\alpha)$, and the recombination rate between markers and the disease. Owing to computational limitations we first used the subset of five markers D16S21-D16S259-D16S125D16S246-D16S80, and then the subset including the highly polymorphic marker D16S85, and D16S259 and D16S125. In the first test, the $\log (\ln )$ likelihood on the assumption of linkage homogeneity was 28.60 compared with 40.42 on the assumption of linkage heterogeneity (one linked and one unlinked ADPKD loci), and 23.24 compared with 42.91 in the second test. The likelihood ratios were $1.36 \times 10^{5}$ (test 1 ) and $3.49 \times 10^{8}$ (test 2), which are significant $\left(\chi^{2} 23.6, \mathrm{p}<0.0001\right.$, and 39.3 , $\mathrm{p}<0.0001$, respectively). Then both tests gave strong evidence in favour of heterogeneity with the estimate of the fraction of chromosome 16 linked families $\alpha=0.85$ (table 3 ).

The maximum multipoint lod score under heterogeneity in the first test $(Z=21.47)$ was obtained by placing PKD1 $2 \mathrm{cM}$ proximal to D16S259 and $1 \mathrm{cM}$ distal to D16S125. In the second test the maximum lod score $(Z=22 \cdot 28)$ was obtained with the disease locus $1.5 \mathrm{cM}$ proximal to D16S259 and $1.5 \mathrm{cM}$ distal to D16S125 (table 3). These estimates are consistent with previous studies that placed PKD1 between these loci. ${ }^{8}$ In the figure, lod scores obtained in multipoint analysis are plotted using a fixed map of three markers (test 2 in table 3 ) under the assumptions of heterogeneity $(\alpha=0.85)$ or homogeneity $(\alpha=1)$, taking the position of D16S259 (pGGG1) as point 0 .

Three families out of 31 analysed show statistically significant evidence of non-linkage to PKD1 (table 4), with probabilities of 0.012 (6002), 0.021 (6008), and 0.000 (6030) that they are linked to PKD1. Two families were considered not to be informative since they have probabilities of linkage of 0.734 (6001) and $0.729(6054)$, with approximate $95 \%$ confidence limits of $0.228-0.904$ and $0.410-0.909$, respectively. All data supported PKD1 being the locus causing the disease in the remaining 26 families (conditional probability of linkage higher than 0.9 in each case). As expected, the maximum two point lod scores between the disease and chromosome 16 markers increased when they were claculated for this group of families (compare A and B in table 2). The only exception is D16S246, which is because 
Table 2 Maximum two point lod scores for linkage between ADPKD and chromosome 16 marker loci.

\begin{tabular}{|c|c|c|c|c|c|c|}
\hline \multirow[b]{2}{*}{ Locus } & \multicolumn{3}{|c|}{ (A) All families (31) } & \multicolumn{3}{|c|}{ (B) Chromosome 16 linked families (26) } \\
\hline & $Z \max$ & $\theta \max$ & $\begin{array}{c}\text { Confidence } \\
\text { interval } \\
(1 \text { lod support })\end{array}$ & $Z$ max & $\theta \max$ & $\begin{array}{c}\text { Confidence } \\
\text { interval } \\
\text { (1 lod support) }\end{array}$ \\
\hline $\begin{array}{l}\text { D16S85 } \\
\text { D16S21 } \\
\text { D16S259 } \\
\text { D16S125 } \\
\text { D16S246 } \\
\text { D16S80 }\end{array}$ & $\begin{array}{r}12 \cdot 45 \\
7 \cdot 44 \\
6 \cdot 74 \\
5 \cdot 87 \\
5 \cdot 08 \\
2 \cdot 98\end{array}$ & $\begin{array}{l}0.091 \\
0.041 \\
0.085 \\
0.025 \\
0.028 \\
0.130\end{array}$ & $\begin{array}{l}(0.045-0 \cdot 165) \\
(0.006-0 \cdot 130) \\
(0.028-0 \cdot 180) \\
(0.001-0 \cdot 125) \\
(0.001-0 \cdot 130) \\
(0.042-0 \cdot 280)\end{array}$ & $\begin{array}{r}16 \cdot 24 \\
8 \cdot 36 \\
9 \cdot 78 \\
7 \cdot 10 \\
4 \cdot 30 \\
5 \cdot 52\end{array}$ & $\begin{array}{l}0.040 \\
0.020 \\
0.019 \\
0.000 \\
0.035 \\
0.000\end{array}$ & $\begin{array}{l}(0.010-0.095) \\
(0.001-0.100) \\
(0.001-0.090) \\
(0.000-0.065) \\
(0.002-0 \cdot 100) \\
(0.000-0 \cdot 110)\end{array}$ \\
\hline
\end{tabular}

Table 3 Homogeneity test between ADPKD and chromosome $16 p$ markers.

\begin{tabular}{|c|c|c|c|c|c|c|c|}
\hline \multirow[b]{2}{*}{$\begin{array}{l}\text { Multipoint } \\
\text { test }\end{array}$} & \multicolumn{4}{|c|}{ Estimates of } & \multirow[b]{2}{*}{$\begin{array}{c}\text { Likelihood } \\
\text { ratios } \\
(\mathrm{H} 2 \text { versus } \mathrm{H} 1)\end{array}$} & \multirow[b]{2}{*}{$\chi^{2}(\mathrm{df})$} & \multirow[b]{2}{*}{$\begin{array}{c}\text { Likelihood } \\
\text { ratios } \\
\text { (H2 versus } \mathrm{H} 0)\end{array}$} \\
\hline & $\alpha$ & $\begin{array}{l}\text { (3 unit } \\
\text { support } \\
\text { interval) }\end{array}$ & $\theta$ & $\begin{array}{l}\text { (3 unit } \\
\text { support } \\
\text { interval) }\end{array}$ & & & \\
\hline $\begin{array}{l}1 \\
2\end{array}$ & $\begin{array}{l}0.85 \\
0.85\end{array}$ & $\begin{array}{l}(0.65-0.95) \\
(0.60-0.95)\end{array}$ & $\begin{array}{l}0.020 \\
0.015\end{array}$ & $\begin{array}{l}(0.01-0.043) \\
(0.00-0.027)\end{array}$ & $\begin{array}{l}1.36 \times 10^{5} \\
3.49 \times 10^{8}\end{array}$ & $\begin{array}{l}23 \cdot 6(1) \\
39 \cdot 3(1)\end{array}$ & $\begin{array}{l}3.59 \times 10^{17} \\
4.33 \times 10^{18}\end{array}$ \\
\hline
\end{tabular}

Marker D16S259 (pGGG1) represents map location 0.00. Test 1 performed in the interval 2BP5(D16S21)-GGG1(D16S259)26.6(D16S125)-218EP6(D16S246)-24.1(D16S80), and test 2 with 3'HVR(D16S85)-pGGG1(D16S259)-26.6(D16S125).

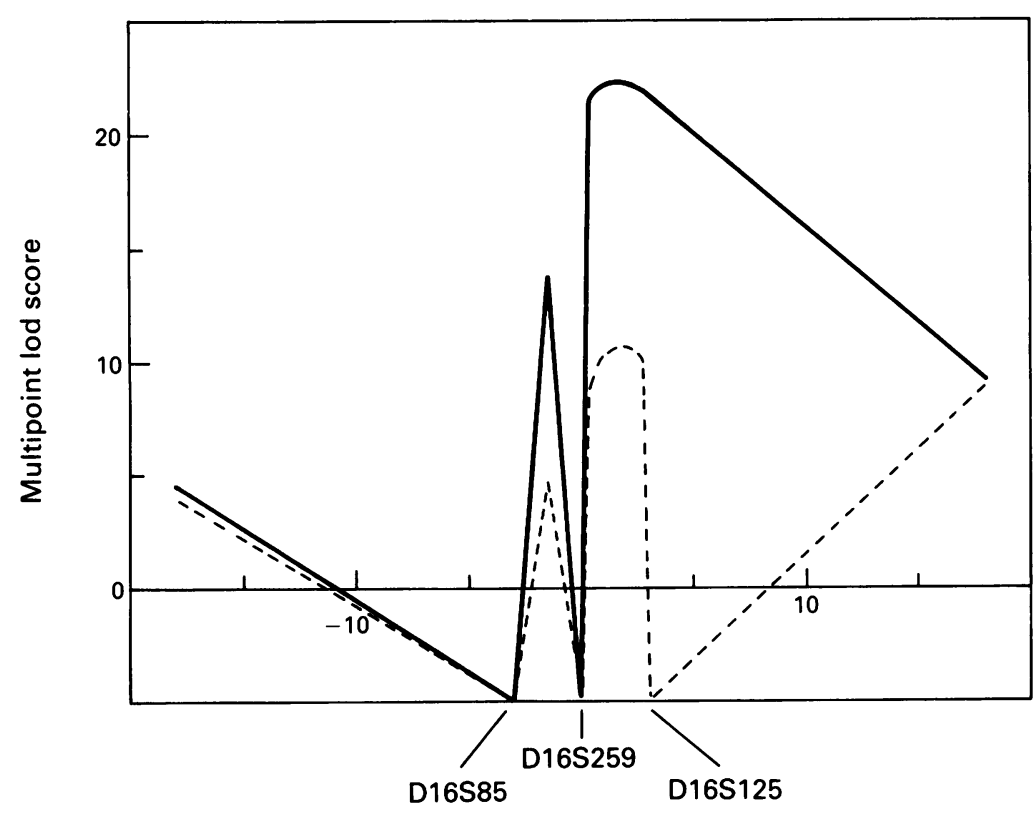

Genetic map (distances in $\mathrm{cM}$ )

Multipoint linkage analysis of ADPKD with polymorphic markers from chromosome $16 p$ under the hypotheses of homogeneity (dashed lines) or heterogeneity (solid lines). this marker was not informative in the families unlinked to PKD1.

Eight recombination events between marker loci and PKD1 were detected. In five cases the subject giving rise to the crossover was a male and in three cases a female. In each case at least one informative flanking marker confirmed the crossover with the disease. Six of these recombination events were observed on the distal side of PKD1, four between D16S85 and PKD1, one between D16S21 and PKD1, and one between D16S259 and PKD1. On the proximal side two recombination events were observed, both between D16S246 and PKD1. One crossover involving a normal and a disease bearing chromosome 16 occurred between D16S259 and D16S125 but, as the subject was too young to express the disease, it was impossible to predict whether the recombination site was proximal or distal to PKD1. No evidence for linkage disequilibrium between any allele of the six marker loci and PKD1 was obtained.

A mutation causing the disease in a Danish family has been suggested to be linked to locus D2S44 on the short arm of chromosome 2 (lod score $2 \cdot 12$ at a recombination fraction of $0 \cdot 10),{ }^{13}$ so we characterised our three 'unlinked' families for the same polymorphism (a PvuII VNTR at locus D2S44). In the three cases negative lod scores for linkage of the disease and D2S44 were obtained (data not shown).

Table 4 Conditional probabilities of linkage to PKD1 are shown for each of 31 ADPKD families studied. The results were obtained using the HOMOG program with data from test 2.

\begin{tabular}{lccc}
\hline Family & $\begin{array}{c}\text { Conditional } \\
\text { probability } \\
\text { of linkage } \\
\text { to PKD1 }\end{array}$ & $\begin{array}{c}\text { Family } \\
\text { No }\end{array}$ & $\begin{array}{c}\text { Conditional } \\
\text { probability } \\
\text { of linkage } \\
\text { to PKD1 }\end{array}$ \\
\hline 6001 & 0.734 & 6039 & 0.912 \\
6002 & 0.012 & 6040 & 0.985 \\
6004 & 0.951 & 6041 & 0.905 \\
6008 & 0.021 & 6046 & 0.977 \\
6012 & 0.954 & 6052 & 0.914 \\
6014 & 0.999 & 6054 & 0.729 \\
6015 & 0.994 & 6056 & 0.957 \\
6020 & 0.968 & 6057 & 0.998 \\
6021 & 1.000 & 6063 & 0.957 \\
6024 & 0.954 & 6064 & 0.905 \\
6025 & 0.954 & 6071 & 0.916 \\
6026 & 0.949 & 6076 & 0.987 \\
6028 & 0.917 & 6077 & 0.972 \\
6030 & 0.000 & 6078 & 0.940 \\
6036 & 0.949 & 6080 & 0.976 \\
6037 & 0.987 & & \\
\hline
\end{tabular}

\section{Discussion}

The results presented in this study provide evidence for genetic heterogeneity of ADPKD in the Spanish population. Two tests, based on multipoint analysis, were significant with likelihood ratios in favour of heterogeneity of over $1 \times 10^{5}$. The frequency of PKD1 linked mutations has been estimated at $85 \%$, the same value as obtained from a study of 273 families from several European countries. ${ }^{19}$ The three non-PKD1 families found in our study also failed to show linkage with a previously described non-PKD1 locus on chromosome $2 .^{13}$ This result suggests that the non-PKD1 mutations may also be genetically heterogeneous. 
Given the locus heterogeneity of the disease, it is essential for genetic predictive diagnosis to show linkage between the disease and reference markers near the PKD1 gene in each family. However, several potential pitfalls exist which can lead to a misleading genetic assignment. Apart from genetic heterogeneity, false negative and false positive diagnoses, double recombinants, gene conversion events, mistyping, or non-paternity can lead to erroneous interpretation of results, so it is important to accumulate as much genetic evidence as possible for the distinction between 'linked' and 'unlinked' families to be made. Different authors have shown that, compared with PKD1, non-PKD1 families have a milder phenotypic expression of the disease, ${ }^{152021}$ and that selection of families through renal clinics is likely to have led to underestimation of the prevalence of non-PKD1. ${ }^{21}$ In our study, $70 \%$ of the families were ascertained by renal clinics and two of the three non-PKD1 probands belong to this group (although they started dialysis at a late age: 63 and 66 years old, respectively).

Previous physical and genetic studies have shown that the PKD1 locus lies in the region between D16S259 (pGGG1) and D16S125 (26.6), a $750 \mathrm{~kb} \mathrm{CpG} \mathrm{rich} \mathrm{region.}{ }^{78}$ Our results also confirm the tight genetic linkage of PKD1 with this region: D16S259 shows only a single definite recombinant with PKD1 $(\theta \max =0.02, \quad Z \max =9.78)$ and $\mathrm{D} 16 \mathrm{~S} 125$ shows no definite recombination with PKD1 $\left(\theta \max =0.00, Z_{\max }=7 \cdot 10\right)$. Multipoint analyses using the 26 PKD1 linked families locate PKD1 between D16S259 and D16S125 with maximum lod scores of 21.50 (test 1 ) and 22.28 (test 2). Fine mapping of this region using new polymorphisms, rare recombinants, and linkage disequilibrium studies will help to give a better insight into the localisation of the PKD1 gene.

We are very grateful to Dr $M$ Breuning for the gift of the DNA probes. This work was supported by grants from the Fondo de Investigaciones Sanitarias (FIS) of the Ministerio de Sanidad y Consumo of Spain, and from the Association Française contre les Myopathies
(AFM). BP and AV were supported by FIS fellowships.

1 Bear JC, McManamon P, Morgan J. Age at clinical onset and at ultrasonographic detection of adult polycystic kidney disease. Data for genetic counselling. $\mathrm{Am} \mathcal{F} \mathrm{Med}$ Genet 1984;18:45-53.

2 Vallés M, García-Garcia $M$. Informe anual del registro de pacientes en diálisis y trasplante renal en España. Nefrologia (Suppl) 1989;9:1-6.

3 Reeders ST, Breuning MH, Davies KE, et al. A highly polymorphic DNA marker linked to adult polycystic kidney disease on chromosome 16. Nature 1985;317:5424.

4 Breuning MH, Snijdewint FGM, Brunner H, et al. Map of 16 polymorphic loci on the short arm of chromosome 16 close to the polycystic kidney disease gene (PKD1). F Med Genet 1990;27:603-13.

5 Germino GG, Barton NJ, Lamb J, et al. Identification of a locus which shows no genetic recombination with the autosomal dominant polycystic kidney disease gene on chromosome 16. Am f Hum Genet 1990;46:925-35.

6 Harris PC, Barton NJ, Higgs DR, Reeders ST, Wilkie AOM. A long-restriction map between the $\alpha$-globin complex and a marker closely linked to the polycystic kidney plex and a marker closely linked to the polycystic

7 Germino GG, Weinstat-Saslow D, Himmelbauer H, et al. The gene for autosomal dominant polycystic kidney disease lies in a 750-kb CpG-rich region. Genomics 992;13:144-51

8 Somlo S, Wirth B, Germino GG, et al. Fine genetic localization of the gene for autosomal dominant polycystic kidney disease (PKD1) with respect to physically mapped markers. Genomics 1992;13:152-8.

9 Bachner L, Vinet MC, Lacave R, et al. Linkage study of a large family with autosomal dominant polycystic kidney disease with reduced expression: absence of linkage to the PKD1 locus. Hum Genet 1990;85:221-7.

10 Kimberling WJ, Fain PR, Kenyon JB, Goldgan D, Sujansky E, Gabow PA. Linkage heterogeneity of autosomal dominant polycystic kidney disease. $N$ Engl $f$ Med mal dominant polyc

11 Romeo G, Devoto M, Costa G, et al. A second locus for autosomal dominant polycystic kidney disease. Lancet 1988;ii:8-11.

12 Feinberg AP, Vogelstein B. A technique for radiolabeling DNA restriction endonuclease fragments to high specific activity. Anal Biochem 1983;132:6-13.

13 Norby S, Schwartz M. Possible locus for polycystic kidney disease on chromosome 2. Lancet 1990;336:323-4

14 Lathrop GM, Lalouel JM. Easy calculations of lod-scores and genetic risks on small computers. Am $\mathcal{f}$ Hum Genet 1988;29:235-9.

15 Parfrey PS, Bear JC, Morgan J, et al. The diagnosis and prognosis of autosomal dominant polycystic kidney disease. $N$ Engl $f$ Med 1990;323:1085-90.

16 Reeders ST, Hildebrand CE. Report of the committee on the genetic constitution of chromosome 16. Cytogenet Cell the genetic constitution of

17 Ott J. Analysis of human genetic linkage. Baltimore: Johns Hopkins University Press, 1985

18 Jarman AP, Nicholls RD, Weatherall DJ, Clegg JB, Higgs DR. Molecular characterisation of a hypervariable region downstream of the alpha-globin gene cluster. EMBO $\mathcal{Y}$ 1986;5:1857-63

19 Peters DJM, Sandkuijl LA. Genetics heterogeneity of polycystic kidney in Europe. Contrib Nephrol 1992;97:128-39.

20 Bear JC, Parfrey PS, Morgan JM, et al. Autosomal domin ant polycystic kidney disease: new information for genetic counselling. Am $\mathcal{F}$ Med Genet 1992;43:548-53.

21 Ravine D, Walker RG, Gibson RN, et al. Phenotype and genotype heterogeneity in autosomal dominant polycystic genotype heterogeneity in autosomal dom
kidney disease. Lancet 1992;340:1330-3. 